\title{
Analysis of the 6-gingerol Content in Zingiber spp. and their Commercial Foods using HPLC
}

\author{
Sunghun Cho $\cdot$ Dong Gu Lee $\cdot$ Sullim Lee $\cdot$ Sungwook Chae* Sanghyun Lee*
}

Received: 21 August 2015 / Accepted: 23 September 2015 / Published Online: 31 December 2015

(C) The Korean Society for Applied Biological Chemistry 2015

\begin{abstract}
The content analysis of 6-gingerol, which is an active compound, in Zingiber spp. (Z. officinale and Z. mioga) and their commercial foods (ginger teas and powders) was conducted using high-performance liquid chromatography. A reverse phase system was used, with a gradient solvent system of water and acetonitrile. The 6-gingerol content was highest in the methanol extract of $Z$. officinale root $(17.09 \mathrm{mg} / \mathrm{g}$ extract) and ginger powder B (15.92 $\mathrm{mg} / \mathrm{g}$ extract). The results demonstrated that this method was simple and reliable for the quality control of Zingiber commercial foods.
\end{abstract}

Keywords 6-gingerol $\cdot$ high-performance liquid chromatography $\cdot$ LOD $\cdot$ LOQ $\cdot$ Zingiber spp.

\section{Introduction}

Zingiber spp. is an important natural material that provides useful products for food, spices, medicines, powders, perfumes, and dietary supplements (Bhunia and Mondal, 2012). It is well known as an ethnomedicine (Tushar et al., 2010), and some varieties,

S. Cho $\cdot$ D. G. Lee $\cdot$ S. Lee

Department of Integrative Plant Science, Chung-Ang University, Anseong 17546, Republic of Korea

S. Lee

Natural Products Research Center, KIST Gangneung Institute, Gangneung 25451, Republic of Korea

S. Chae

KM Convergence Research Division, Korea Institute of Oriental Medicine, Daejeon 34054, Republic of Korea

*Corresponding authors (S.Lee: slee@cau.ac.kr, S.Chae:kendall@kiom.re.kr)

This is an Open Access article distributed under the terms of the Creative Commons Attribution Non-Commercial License (http://creativecommons. org/licenses/by-nc/3.0/) which permits unrestricted non-commercial use, distribution, and reproduction in any medium, provided the original work is properly cited. such as Z. cassumunar, Z. officinale, Z. zerumbet, and Z. mioga, are used in traditional medicine (Devi et al., 2014).

Ginger is the dried rhizome of Z. officinale (Mowrey and Clayson, 1982), and has been used as a spice for over 2000 years (Bartley and Jacobs, 2000). It is cultivated in many tropical and subtropical countries including Australia, Nigeria, and Haiti; however, China and India are world's leading producers (Pawar et al., 2011). In Western herbal medicine, ginger is used as a treatment for colds, rheumatism, sore throats, and for digestive disorders, which include dyspepsia, vomiting, gastritis, nausea, and diarrhea (Zick et al., 2010). Moreover, ginger has been investigated in vitro and in animal models for its cancer prevention (Mowrey and Clayson, 1982), anti-inflammatory (Ghayur et al., 2005), and anti-diabetic activities (Al-Amin et al., 2006). Ginger has recently been increasingly used because of its low toxicity and the broad spectrum of its biological and pharmacological applications, such as its anti-tumor, anti-apoptotic, anti-oxidant, anti-proliferative, cytotoxic, and anti-platelet activities (Sekiwa et al., 2000; Young et al., 2005; Wei et al., 2005; Shukla and Singh, 2007).

All of the pungent compounds in ginger contain 4-hydroxy-3methoxyphenyl moieties and ketone functional groups in their structures (Zick et al., 2010). The main classes of pungent or phenolic compounds in ginger are the gingerols, shogaols, paradols, and zingerones (Chrubasik et al., 2005). Gingerols are the major compounds and are biologically active constituents in the fresh roots. Shogaols are only found in small quantities in the fresh root, but are typically found in dried or thermally treated roots as 6shogaol (Jolad et al., 2004). Among these compounds, 6-gingerol was found to possess anti-oxidative activity through the inhibition of phospholipid peroxidation (Aeschbach et al., 1994). Furthermore, 6-gingerol inhibits phorbol ester-induced inflammation, epidermal ornithine decarboxylase activity, and skin tumor promotion in mice (Park et al., 1998), and has an inhibitory effect on xanthine oxidase, which is responsible for the generation of reactive oxygen species such as superoxide anions (Chang et al., 1994).

Many analytical methods, which include gas chromatography coupled with mass spectrometry, liquid chromatography coupled 
with mass spectrometry, nuclear magnetic resonance, thin layer chromatography, and capillary electrophoresis have been used for the analysis of gingerol-related compounds in ginger (Connell and McLachlan, 1972; Huang et al., 1997; He et al., 1998; Catchpole et al., 2003; Jolad et al., 2004).

The objective of this study was to analyze the 6-gingerol content of Zingiber spp. (Z. officinale and Z. mioga) and their commercial products (ginger teas and powders) using highperformance liquid chromatography (HPLC).

\section{Materials and Methods}

Plant materials and commercial foods. Z. officinale root was obtained from Omniherb Co., Ltd. (Korea). The methanol $(\mathrm{MeOH})$ extracts of aerial and root parts of $Z$. officinale, and the whole plant and root parts of Z. mioga, were purchased from the Korea Plant Extract Bank, Korea Research Institute of Bioscience and Biotechnology (KRIBB), Korea. Five ginger teas and two powders were purchased as commercial foods from Local Mart, Korea.

Apparatus and chemicals. Evaporation was conducted with an evaporator system (Eyela rotary vacuum evaporator N1100, Tokyo Rikakikai Co. Ltd., Japan) under reflux in vacuo. The HPLC analysis was performed using a Waters Breeze system (Waters Co., USA) equipped with a Waters 1525 binary HPLC pump and a 2489 system UV/VIS detector. The water, $\mathrm{MeOH}$, and acetonitrile (ACN) used were of HPLC grade, and all other reagents were of analytical grade. 6-Gingerol (Fig. 1) was purchased from Sigma-Aldrich (USA).

Preparation of standards and samples. 6-Gingerol was weighed and dissolved in $80 \% \mathrm{MeOH}$ to obtain a stock standard solution $(1.0 \mathrm{mg} / \mathrm{mL})$. Aqueous 6-gingerol solutions were prepared at concentrations of $0.016,0.031,0.062,0.125,0.25,0.5$, and $1 \mathrm{mg} /$ $\mathrm{mL}$ for the construction of a calibration curve. For the analysis of 6-gingerol in the ginger and commercial foods, $5 \mathrm{~g}$ of each were extracted using $\mathrm{MeOH}(3 \times 250 \mathrm{~mL})$ under reflux and then evaporated in vacuo. Each extract was dissolved in $1 \mathrm{~mL}$ of $80 \%$ $\mathrm{MeOH}$ and filtered through a $0.45-\mu \mathrm{m}$ filter before the HPLC analysis.

HPLC conditions. The HPLC separation of 6-gingerol for its qualitative and quantitative analysis was performed using a reverse phase system. A Waters Spherisorb ${ }^{\circledR}$ INNO C18 $(4.6 \times 250 \mathrm{~mm}$, $5 \mu \mathrm{m}$ ) column was used with a mobile phase, which consisted of a gradient solvent system of water (containing $0.2 \%$ acetic acid) and ACN (from 50:50 to 100:0 over $20 \mathrm{~min}$ ). UV detection was conducted at $230 \mathrm{~nm}$, the injection volume was $10 \mu \mathrm{L}$, and the flow rate was $1 \mathrm{~mL} / \mathrm{min}$. All injections were performed in triplicate. Limits of detection and quantification (LOD and LOQ). Validation of the HPLC method for 6-gingerol as a standard compound was performed using the LOD and LOQ. The method linearity was established using triplicate injections in the range of $0.016-1 \mathrm{mg} / \mathrm{mL}$. Seven calibration solutions were injected in triplicate and their analyses were performed. Calibration curves<smiles>CCCCCC(O)CC(=O)CCc1ccc(O)c(OC)c1</smiles>

Fig. 1 Structure of 6-gingerol.

were constructed using linear regression analysis of the peak area ratios (Y) corresponding to 6-gingerol versus its concentration (X) in $\mathrm{mg} / \mathrm{mL}$. The relative standard deviation was used as a measure of repeatability. The percent recoveries were evaluated by calculating the ratio of amount of 6-gingerol detected versus the amount added. The LOD and LOQ values were separately determined at signal to noise ratios $(\mathrm{S} / \mathrm{N})$ of 3 and 10 , respectively. Calibration curve. Stock solutions $(0.016-1 \mathrm{mg} / \mathrm{mL})$ of 6gingerol were prepared in $80 \% \mathrm{MeOH}$. The 6-gingerol contents of the samples were determined using the corresponding calibration curves. The calibration curve for 6-gingerol was calculated using the peak area $(\mathrm{Y})$, concentration $(\mathrm{X}, \mathrm{mg} / \mathrm{mL})$, and mean values ( =3) \pm standard deviation (SD).

\section{Results and Discussion}

We determined the 6-gingerol contents of Zingiber spp. and their commercial foods using HPLC. The HPLC separations and analyses were performed using a reverse phase system with a mobile phase consisting of water and ACN gradient (50:50 to 100:0 over $20 \mathrm{~min}$ ) and 6-gingerol was detected using a UV-Vis detector at $230 \mathrm{~nm}$. The HPLC chromatograms of 6-gingerol, $Z$. officinale root, Z. mioga root (KRIBB), ginger tea $\mathrm{C}$, and ginger powder B are shown in Fig. 2. The 6-gingerol concentration of the $Z$. officinale root extract from Omniherb was determined to be $13.24 \mathrm{mg} / \mathrm{g}$ extract. The 6-gingerol contents of the aerial part of $Z$. officinale, root of $Z$. officinale, whole plant of $Z$. mioga, and root of $Z$. mioga from KRIBB were determined to be $0.83,17.09,0.28$, and $0.16 \mathrm{mg} / \mathrm{g}$ of extract, respectively (Table 1). The 6-gingerol content of $Z$. officinale was higher than that of $Z$. mioga. In addition, the 6-gingerol content in aerial part of the ginger was higher than that in the roots. 6-Gingerol is the major compound isolated from Z. officinale (Jolad et al., 2004). However, the major pungent compounds of $Z$. mioga were miogadial, mioganal, galanal A, and galanal B (Kim et al. 2005). In previous papers, HPTLC method was reported and validated for estimation of 6gingerol in dried rhizome extracts of $Z$. officinale with high precision (Kumar et al. 2012). HPLC method was allowed for the detection of all ginger's pungent constituents simultaneously in run time of 25 minutes (Zick et al., 2010).

Additionally, the 6-gingerol concentrations of ginger teas and powders were determined (Tables 2 and 3). With regard to these commercial foods, the 6-gingerol content was highest in ginger powder B, with a concentration of $15.92 \mathrm{mg} / \mathrm{g}$ extract. Originally, the products of ginger powder A and B contain $36.8 \%$ and $100 \%$ ginger powders, respectively. In general, the 6-gingerol contents 
(A)

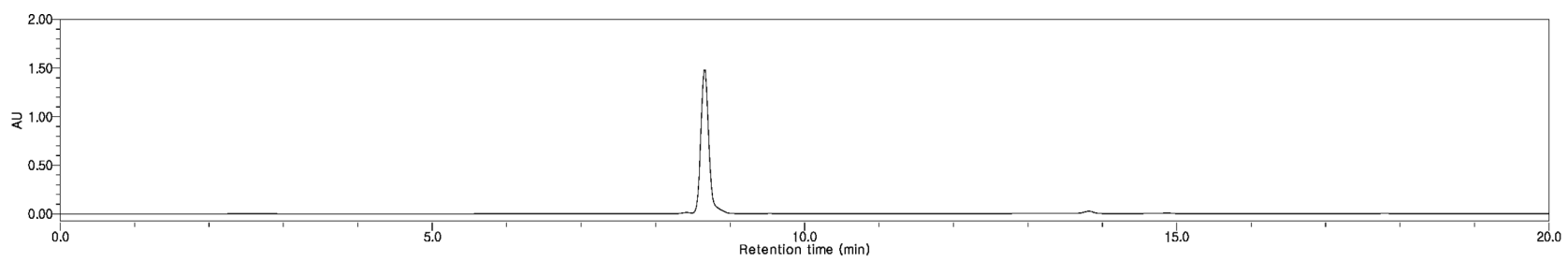

(B)

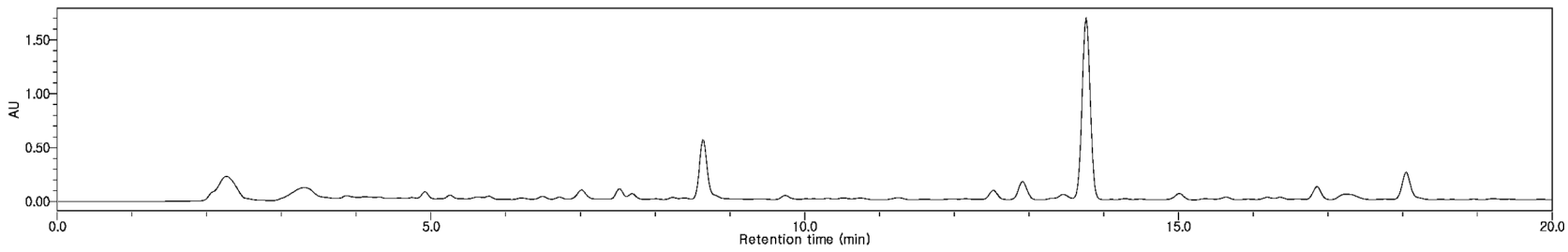

(C)

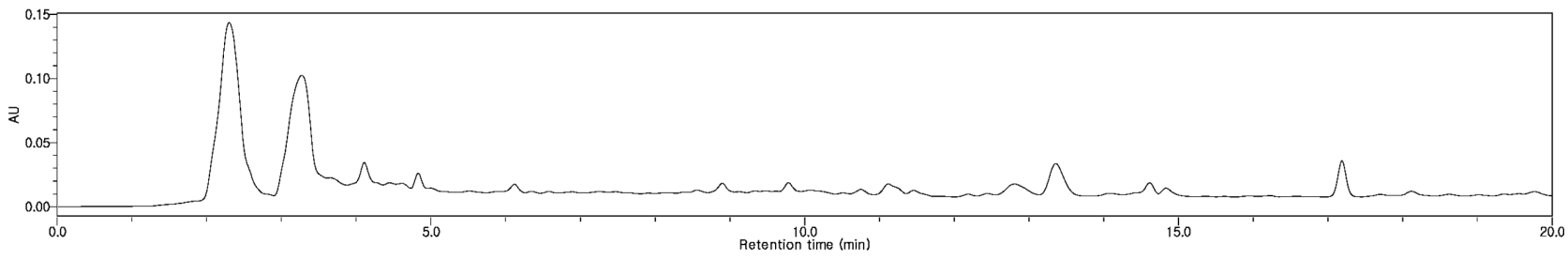

(D)

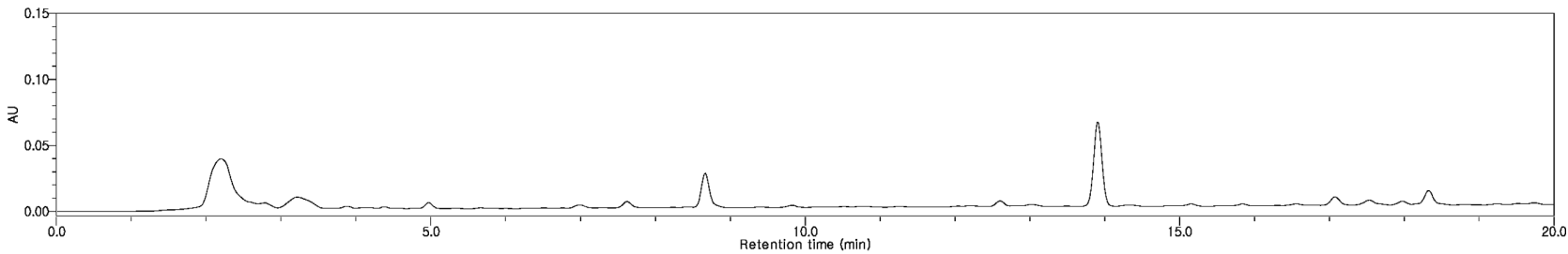

(E)

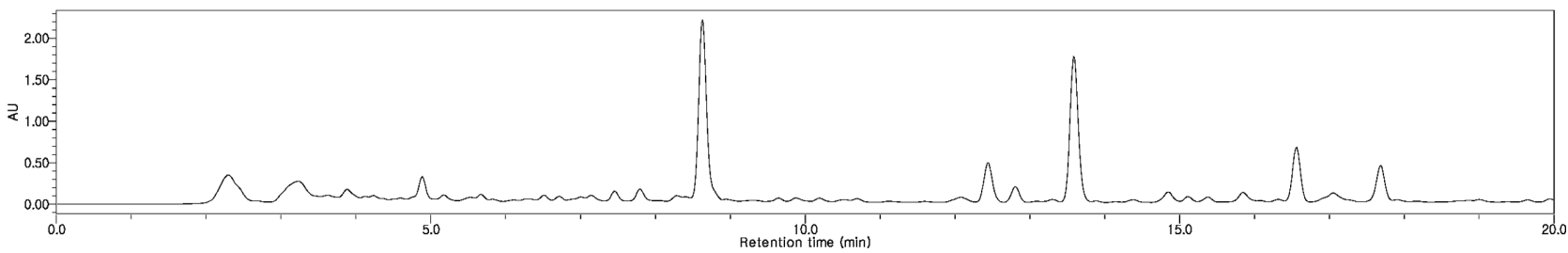

Fig. 2 HPLC chromatograms of 6-gingerol (A), the MeOH extract of Z. officinale root from KRIBB (B), Z. mioga root from KRIBB (C), ginger tea C (D), and ginger powder B (E).

Table 1 6-Gingerol contents of the $\mathrm{MeOH}$ extracts of Zingiber spp.

\begin{tabular}{lc}
\hline \multicolumn{1}{c}{ Sample } & Content (mg/g extract) \\
\hline Z. officinale root $^{a}$ & $13.24 \pm 0.55$ \\
Z. officinale (aerial part) & $0.83 \pm 0.05$ \\
Z. officinale root $^{b}$ & $17.09 \pm 0.10$ \\
Z. mioga (whole plant) & $0.28 \pm 0.01$ \\
Z. mioga root & $0.16 \pm 0.01$ \\
\hline
\end{tabular}

Data are represented as the mean $\pm \mathrm{SD}(n=3) \mathrm{in} \mathrm{mg} / \mathrm{g}$ extract.

${ }^{a}$ Root of $Z$. officinale was purchased from Omniherb.

${ }^{b}$ Root of $Z$. officinale was purchased from KRIBB.

of the ginger powders were higher than those of the ginger teas. In a previous study, the 6-gingerol contents of three ginger beverages (in granule form), five ginger tea bags (dried rhizome
Table 2 6-Gingerol contents of the $\mathrm{MeOH}$ extracts of ginger teas

\begin{tabular}{cc}
\hline Sample & Content $(\mathrm{mg} / \mathrm{g}$ extract $)$ \\
\hline Ginger tea A & $0.11 \pm 0.01$ \\
Ginger tea B & $0.09 \pm 0.01$ \\
Ginger tea C & $0.78 \pm 0.09$ \\
Ginger tea D & $0.07 \pm 0.01$ \\
Ginger tea E & $0.01 \pm 0.01$ \\
\hline
\end{tabular}

Data are represented as the mean $\pm \mathrm{SD}(n=3) \mathrm{in} \mathrm{mg} / \mathrm{g}$ extract.

Table 3 6-Gingerol contents of the MeOH extracts of ginger powders

\begin{tabular}{cc}
\hline Sample & Content $(\mathrm{mg} / \mathrm{g}$ extract $)$ \\
\hline Ginger powder A & $1.34 \pm 0.01$ \\
Ginger powder B & $15.92 \pm 0.35$ \\
\hline
\end{tabular}

Data are represented as the mean $\pm \mathrm{SD}(n=3)$ in $\mathrm{mg} / \mathrm{g}$ extract. 
Table 4 LOD and LOQ of 6-gingerol

\begin{tabular}{cccccc}
\hline Compound & Calibration equation $^{\mathrm{a}}$ & $r^{2 \mathrm{~b}}$ & Linear range $(\mathrm{mg} / \mathrm{mL})$ & $\mathrm{LOD}(\mathrm{mg} / \mathrm{mL})$ & $\mathrm{LOQ}(\mathrm{mg} / \mathrm{mL})$ \\
\hline 6-gingerol & $\mathrm{Y}=156911 \mathrm{X}+236.8$ & 0.9999 & $0.016-1$ & 0.048 & 0.164
\end{tabular}

${ }^{a} Y=$ peak area, $X=$ concentration of standard $(\mu \mathrm{g} / \mathrm{mL})$.

$\mathrm{b} r^{2}=$ correlation coefficient for three data points in the calibration curve.

and leaves), and three ginger powders (dried ginger rhizome) were determined. Among them, the 6-gingerol contents of the ginger powders were almost $\sim 35-80$ times higher than those of the ginger beverages (Shao et al., 2010).

Therefore, ginger powders are the best source of 6-gingerol, and they are important natural medicinal foods. The 6-gingerol content of ginger powders is associated with various pharmacological and physiological effects, which include cholagogic, anti-cancer, apoptotic, anti-oxidant, cardiotonic, and anti-tumor activities (Shoji et al., 1982; Suekawa et al., 1984; Hiking et al., 1985).

The 6-gingerol content of Zingiber spp. extracts and commercial foods, such as ginger teas and powders, was quantified using the linear regression equation. The linear regression data from the extracts had a good linear relationship and the resulting equation was valid over the relevant concentration range. The linear calibration equation was $\mathrm{Y}=10889 \mathrm{X}+61399$, where $\mathrm{Y}$ is peak area and $\mathrm{X}$ is concentration of 6-gingerol. It had a correlation coefficient $\left(r^{2}\right)$ of 0.9996 . The LOD and LOQ under our chromatographic conditions were determined at signal to noise ratios $(\mathrm{S} / \mathrm{N})$ of 3 and 10, respectively. The LOD and LOQ values for 6-gingerol were determined to be 0.048 and $0.164 \mathrm{mg} / \mathrm{mL}$, respectively (Table 4).

In this work, the 6-gingerol contents of Zingiber spp. and their commercial foods were determined qualitatively and quantitatively using an HPLC method. This HPLC analysis provided useful information accurately, rapidly, and easily. The results demonstrated that this method was simple and reliable for the quality control of Zingiber commercial foods.

Acknowledgment This research was supported by the National Research Foundation of Korea (NRF) funded by the Ministry of Science, ICT \& Future Planning (No. 2006-2005173) and grants (K14101) from the Korea Institute of Oriental Medicine.

\section{References}

Aeschbach R, Loliger J, Scott BC, Murcja A, Butler J, Halliweii B et al (1994) Antioxidant actions of thymol, carvacrol, 6-gingerol, zingerone and hydroxytyrosol. Food Chem Toxicol 32(1), 31-6.

Al-Amin ZM, Thomson M, Al-Qattan KK, Peltonen-Shalaby R, and Ali M (2006) Anti-diabetic and hypolipidaemic properties of ginger (Zingiber officinale) in streptozotocin-induced diabetic rats. Br J Nutr 96(4), 6606.

Bartley JP and Jacobs AL (2000) Effects of drying on flavour compounds in Australian grown ginger (Zingiber officinale). J Sci Food Agric 80(2), 209-15.

Bhunia D and Mondal AK (2012) Antibacterial activity of Alpinia L. (Zingiberaceae) from Santal and Lodha Tribal areas of Paschim Medinipur Districts in Eastern India. Adv Biores 3(1), 54-63.

Catchpole OJ, Grey JB, Perry NB, Burgess EJ, Redmond WA, and Porter NG (2003) Extraction of chili, black pepper, and ginger with near-critical
$\mathrm{CO}_{2}$, propane, and dimethyl ether: Analysis of the extracts by quantitative nuclear magnetic resonance. J Agric Food Chem 51(17), 4853-60.

Chang WS, Chang YH, Lu FI, and Chang HC (1994) Inhibitory effects of phenolics on xanthine oxidase. Anticancer Res 14(2A), 501-6.

Chrubasik S, Pittler MH, and Roufogalis BD (2005) Zingiberis rhizoma: A comprehensive review on the ginger effect and efficacy profiles. Phytomedicine 12(9), 684-701.

Connell DW and McLachlan R (1972) Natural pungent compounds: IV. Examination of the gingerols, shogaols, paradols and related compounds by thin-layer and gas chromatography. J Chromatograph A 67(1), 29-35.

Devi NB, Singh PK, and Das AK (2014) Ethnomedicinal utilization of Zingiberaceae in the Valley Districts of Manipur. IOSR J Environ Sci Toxicol Food Technol 8(2), 21-3.

Ghayur MN, Gilani AH, Afridi MB, and Houghton PJ (2005) Cardiovascular effects of ginger aqueous extract and its phenolic constituents are mediated through multiple pathways. Vascul Pharmacol 43(4), 234-41.

He X, Bernart MW, Lian L, and Lin L (1998) High-performance liquid chromatography-electrospray mass spectrometric analysis of pungent constituents of ginger. J Chromatograph A 796(2), 327-34.

Hiking H, Kiso Y, Kato N, Hamada Y, Shiori T, Aiyama R et al. (1985) Antihepatotoxic action of gingerols and diarylheptanoids. J Ethnopharmacol 14(1), 31-9.

Huang HY, Kuo KL, and Hsieh YZ (1997) Determination of cinnamaldehyde, cinnamic acid, paeoniflorin, glycyrrhizin and [6]-gingerol in the traditional Chinese medicinal preparation Kuei-chih-tang by cyclodextrin-modified micellar electrokinetic chromatography. J Chromatograph A 771(1-2), 267-74.

Jolad SD, Lantz RC, Solyom AM, Chen GJ, Bates RB, and Timmermann BN (2004) Fresh organically grown ginger (Zingiber officinale): Composition and effects on LPS-induced $\mathrm{PGE}_{2}$ production. Phytochemistry 65(13), 1937-54.

Kim HW, Murakami A, Abe M, Ozawa Y, Morimitsu Y, Williams MV et al. (2005) Suppressive effects of mioga ginger and ginger constituents on reactive oxygen and nitrogen species generation, and the expression of inducible pro-inflammatory genes in macrophages. Antioxid Redox Signal 7(11-12), 1621-9.

Kumar KS, Manasa B, Rahman K, and Sudhakar B (2012) Development and validation of hptlc method for estimation of 6-gingerol in herbal formulations and extracts. Int J Pharm Sci Res 3(10), 3762-5.

Mowrey DB and Clayson DE (1982) Motion sickness, ginger, and psychophysics. Lancet 319(8273), 655-7.

Park KK, Chun KS, Lee JM, Lee SS, and Surh YJ (1998) Inhibitory effects of 6-gingerol, a major pungent principle of ginger, on phorbol ester-induced inflammation, epidermal ornithine decarboxylase activity and skin tumor promotion in ICR mice. Cancer Lett 129(2), 139-44.

Pawar N, Pai S, Nimbalkar M, and Dixit G (2011) RP-HPLC analysis of phenolic antioxidant compound 6-gingerol from different ginger cultivars. Food Chem 126(3), 1330-6.

Sekiwa Y, Kubota K, and Kobayashi A (2000) Isolation of novel glucosides related to gingerdiol from ginger and their antioxidative activities. $J$ Agric Food Chem 48(2), 373-7.

Shao X, Lv L, Parks T, Wu H, Ho CT, and Sang S (2010) Quantitative analysis of ginger components in commercial products using liquid chromatography with electrochemical array detection. J Agric Food Chem 58(24), 12608-14.

Shoji N, Iwasa A, Takemoto T, Ishida Y, and Ohizumi Y (1982) Cardiotonic principle of ginger (Zingiber officinale Roscoe). J Pharmaceut Sci 71(10), 1174-5. 
Shukla Y and Singh M (2007) Cancer preventive properties of ginger: A brief review. Food Chem Toxicol 45(5), 683-90.

Suekawa M, Ishige A, Yuasa K, Sudo K, Aburada M, and Hosoya E (1984) Pharmacological studies on ginger. I. Pharmacological action of pungent constituents, (6)-gingerol and (6)-shogaol. J Pharm Sci 7(11), 836-48.

Tushar, Basak S, Sarma GC, and Rangan L (2010) Ethnomedicinal uses of Zingiberaceous plants of Northeast India. J Ethnopharmacol 132(1), 286-96.

Wei QY, Ma JP, Cai YJ, Yang L, and Liu ZL (2005) Cytotoxic and apoptotic activities of diarylheptanoids and gingerol-related compounds from the rhizome of Chinese ginger. J Ethnopharmacol 102(2), 177-84.

Young HY, Luo YL, Cheng HY, Hsieh WC, Liao JC, and Peng WH (2005) Analgesic and anti-inflammatory activities of [6]-gingerol. J Ethnopharmacol 96(1-2), 207-10.

Zick SM, Ruffin MT, Djuric Z, Normolle D, and Brenner DE (2010) Quantitation of 6-, 8- and 10-gingerols and 6-shogaol in human plasma by high-performance liquid chromatography with electrochemical detection. Int J Biomed Sci 6(3), 233-40. 